\title{
Analisis Perkerasan Lentur Landas Pacu Bandar Udara Juanda Dengan Membandingkan Aspal Shell Dengan Aspal Pertamina
}

\author{
Ary Wahyudi dan Ervina Ahyudanari \\ Departemen Teknik Sipil, Fakultas Teknik Sipil dan Perencanaan, Institut Teknologi Sepuluh \\ Nopember (ITS) \\ e-mail:ervina@ce.its.ac.id
}

\begin{abstract}
Abstrak-Kondisi perkerasan lentur runway bandara di Indonesia memiliki beragam karakteristik material yang berbeda-beda dengan tipe perkerasan lentur menggunakan aspal minyak sebagai pengikat dan agregat serta filler atau pengisi campuran aspal. Kerusakan aspal yang pernah terjadi di Indonesia diantaranya adalah terkelupasnya aspal dibeberapa titik di landasan Bandara Juanda, lalu kasus lain yang terjadi di Bandara Ngurah Rai, Bali yaitu terkelupasnya aspal di sekitar ujung barat landas pacu 09. Dengan contoh kasus kerusakan tersebut, studi ini disusun dengan tujuan untuk mengetahui penyebab kerusakan pada landasan yang berhubungan dengan karakteristik aspal. Dari hasil uji karakteristik aspal didapat untuk aspal Shell nilai penetrasi sebesar $63.2 \mathrm{~mm}$, nilai titi lembek sebesar53.2 $\mathrm{C}$, nilai titik nyala dan titik bakar sebesar $302^{\circ} \mathrm{C}$ dan $324^{\circ} \mathrm{C}$, nilai daktilitas sebesar $141.5 \mathrm{~cm}$, dan nilai berat jenis sebesar $1.033 \mathrm{gr} / \mathrm{m}^{3}$ sedangkan hasil uji aspal Pertamina didapat nilai penetrasi sebesar $63.9 \mathrm{~mm}$, nilai titik lembek $52.5^{\circ} \mathrm{C}$, nilai titik nyala dan titik bakar sebesar $280^{\circ} \mathrm{C}$ dan $310^{\circ} \mathrm{C}$, nilai daktilitas sebesar $139.5 \mathrm{~cm}$, dan nilai berat jenis sebesar $1.028 \mathrm{gr} / \mathrm{m}^{3}$. Dibutuhkan material aspal yang memiliki karakteristik dengan kemampuan ketahanan terhadap panas sehingga mampu mempertahankan kondisi sifat rheologi, thermoplastic, dan thixotropy. Namun dari perbedaan yang kecil ini memungkinkan dilakukan studi lebih lanjut untuk mengetahui hal-hal yang mempengaruhi perbedaan ini walaupun secara kriteria aspal memiliki nilai yang sama yaitu pada kriteria penetrasi60/70.
\end{abstract}

Kata kunci-Perkerasan lentur runway, Aspal Pertamina, Aspal Shell, Marshall Test dan Wheel Tracking Test.

\section{PENDAHULUAN}

$\mathrm{R}$ UNWAY merupakan infrastruktur yang berfungsi sebagai landasan pesawat terbang melakukan lepas landas dan pendaratan. Sebagai infrastruktur yang digunakan untuk akses utama pesawat terbang dalam melakukan pergerakan, kualitas runway diharapkan dapat memberikan kenyamanan dan keselamatan penerbangan. Oleh sebab itu, diperlukan alternatif material yang mampu menghasilkan kinerja aspal beton optimum untuk runway bandara.

Aspal menjadi komponen penting dalam perencanaan perkerasan lentur. Hal ini yang menjadi salah satu sebab keberagaman karakterisitk kualitas perkerasan lentur bandara di Indonesia. Aspal yang sering digunakan menjadi komposisi perkerasan lentur di Indonesia pada umumnya yaitu aspal produksi lokal atau aspal Pertamina. Dari salah satu sumber yang kami ambil menyimpulkan bahwa pada pengujian karakteristik Marshall kadar aspal optimum, campran Laston AC-WC yang menggunakan aspal BNA Blend 75/25 memiliki karakteristik lebih baik dibanding
Laston AC/WC yang menggunakan aspal Pertamina Pen 60/70 [1]. Dengan nilai MQ yang lebih rendah menunjukkan kemampuan Laston dengan aspal Pertamina kurang optimum dalam menerima repitisi beban lalu lintas, gesekan roda kendaraan pada permukaan jalan dan kemampuan menahan keausan karena pengaruh perubahan temperatur. Aspal Shell adalah salah satu produk lain yang digunakan dunia internasional sebagai bahan penyusun perkerasan aspal. Aspal Shell memiliki kualitas titik lembek yang lebih tinggi jika dibandingkan dengan aspal Pertamina. Namun, apakah hal ini sangat berpengaruh pada kualitas aspal Shell dibanding aspal Pertamina.

Di sisi lain kerusakan aspal yang pernah terjadi di Indonesia diantaranya adalah terkelupasnya aspal dibeberapa titik di landasan Bandara Juanda, lalu kasus lain yang terjadi di Bandara Ngurah Rai, Bali yaitu terkelupasnya aspal di sekitar ujung barat landas pacu 09. Kasus seperti ini umumnya disebabkan oleh pembebanan yang terjadi berlebihan (overload) atau panas akibat temperatur lingkungan maupun panas yang dihasilkan mesin jet. Selain itu, kerusakan aspal juga disebabkan karena terlalu tingginya viskositas aspal keras saat pencampuran dengan agregat akibat tidak berjalannya pengendalian mutu di AMP sehingga temperatur aspal tidak terkontrol. Jenis kerusakan yang sering terjadi pada laston adalah pelepasan butiran dan retak. Kondisi ini salah satu jurnal yang kami ambil yaitu pengaruh beban pesawat yang berlebih jika dibanding dengan kekuatan perkerasan, hal ini menyebabkan kondisi landasan di bandara Juanda mengalami beberapa kerusakan, seperti cracking, rutting (alur), dan pengelupasan. Kondisi sepert ini sangat diperhitungkan dalam dunia penerbangan. Salah satu standardisasi yang dilakukan adalah penggunaan material aspal dalam menyusun perkerasan lentur [2].

Dengan kondisi-kondisi di atas menjadi pertimbangan studi ini disusun dengan tujuan untuk mengetahui apakah kerusakan pada landasan berhubungan dengan karakteristik aspal yang digunakan pada perkerasan tersebut dan untuk mendapatkan kualitas aspal yang optimum sebagai acuan perencanaan perkerasan lentur runway serta studi ini akan membandingkan aspal produksi lokal atau aspal Pertamina dengan aspal impor yaitu aspal Shell dengan metode FAA. Sampel yang akan diambil berasal dari spesifikasi runway Bandara Juanda, Surabaya. 


\section{METODE PENELITIAN}

Studi ini dilakukan untuk mengetahui kualitas perkerasan lentur yang ada di landas pasu bandar udara Juanda dan melakukan perbandingan komposisi campuran aspal dengan menggunakan dua jenis pengikat yang berbeda, pengikat yang digunakan adalah aspal pertamina penetrasi 60/70 dengan aspal shell dengan penetrasi 60/70. Studi ini dilakukan dalam tiga tahap, yaitu :

- Mengumpulkan data skunder dari runway Bandara Juanda

- Pekerjaan persiapan dan pemeriksaan kelayakan bahan yang akan digunakan

- Pembuatan benda uji dan analisis campuran aspal Pada tahap pertama, dilakukan pengumpulan data skunder yang didapat dari Angkasa Pura II, data tentang overlay runway Bandara Juanda.

Pada tahap kedua, dilakukan persiapan material yang akan digunakan antara lain aspal dan agregat. Setelah semua material terkumpul, maka dilakukan pengujian standar untuk mengetahui karakteristik masing-masing material. Untuk material aspal akan dilakukan beberapa pengujian sebagai berikut :

- Pemeriksaan penetrasi aspal

- Pemeriksaan titik lebek aspal

- Pemeriksaan titik nyala dan titik bakar

- Pemeriksaan daktilitas bahan-bahan bitumen

- Pemeriksaan berat jenis bitumen

Untuk mengetahui karakteristik dari agregat yang digunakan akan dilakukan beberapa pengujian sebagai berikut :

- Berat jenis dan penyerapan agregat kasar

- Berat jenis dan penyerapan agregat halus

- Abrasi dengan mesin Los Angeles

- Analisa butiran (Sieve Analysis)

Setelah mendapatkan data karakteristik material yang akan digunakan, maka data yang diperoleh dibandingkan dengan spesifikasi. Jika material yang diperoleh tidak sesuai dengan standar yang ditentukan akan dilakukan pemeriksaan ulang

Pada tahap ketiga, dilakukan mix design sebanyak 5 jenis benda uji yang mana masing-masing benda uji memiliki kadar aspal yang berbeda. Setelah dilakukan mix design kemudian dilakukan uji Marshall untuk mendapatkan nilai stabilitas, flow, Marshall Quotient, dan data lainnya.

\section{HASIL DAN PEMBAHASAN}

\section{A. Karakteristik Material di Runway Bandara Juanda}

Pada sub bab ini penulis akan menyajikan data skunder berupa hasil uji material aspal dan agregat yang digunakan untuk campuran aspal beton pada overlay runway Bandara Juanda, Surabaya. Hasil uji karakteristik sebagai berikut :

1) Uji Material Aspal

Data skunder yang penulis sajikan ini dilaksanakan oleh PT. Makassar Indah Graha Sarana. Pada laporan ini dilakukan beberapa pengujian diantara :

1. Uji Penetrasi

2. Uji Titik Lembek Aspal

3. Uji Titik Nyala/Titik Bakar

4. Uji Daktilitas

5. Uji Berat Jenis

Tujuan dari pengujian ini adalah untuk mengendalikan mutu aspal agar sesuai dengan spesifikasi perencanaan.

\section{2) Pemeriksaan Nilai Penetrasi Aspal}

Metode yang digunakan dalam pemeriksaan nilai penetrasi aspal adalah metode yang berdasarkan SNI-06-2456-1991 tentang Metode Pegujian Penetrasi Bahan-bahan Bitumen. Pemeriksaan ini bertujuan untuk mendapatkan angka penetrasi pada aspal keras atau lembek [3]. Angka penetrasi menunjukkan konsistensi aspal yang selanjutnya dapat digunakan dalam pekerjaan pengendalian mutu aspal dan untuk pembangunan atau pemeliharaan jalan (SNI 06-24561991)[4]. Dari hasil uji penetrasi didapat

Tabel 1

Hasil uji penetrasi aspal eksisting

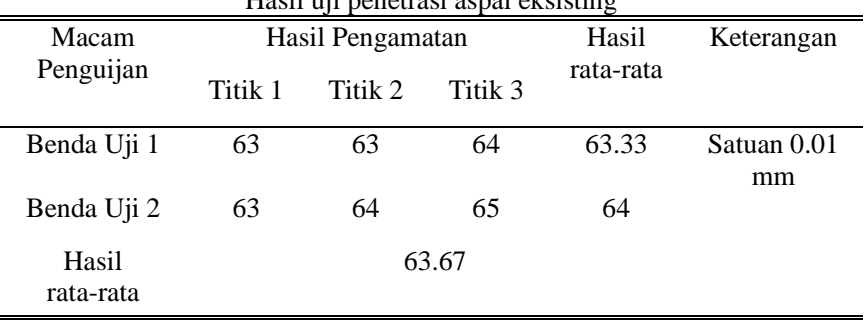

\section{3) Pemeriksaan Nilai Titik Lembek Aspal Eksisting}

Pemeriksaan aspal yang mengacu pada SNI-06-2434-2011 dan ASTM D-36 ini bertujuan untuk menentukan titik lembek aspal yang berkisar antara $30^{\circ} \mathrm{C}$ sampai $200^{\circ} \mathrm{C}[3]$. Pada dasarnya semua jenis aspal bersifat thermoplastic, yaitu dapat berubah sifat tergantung temperatur dimana bila dipanaskan menjadi lunak dan menjadi keras bila didinginkan. Kepekaan terhadap temperatur dapat ditunjukkan dengan nilai Indeks Penetrasi (PI)[4]. Hasil uji titik lembek aspal eksisting adalaah sebagai berikut

Tabel 2

Hasil uji titik lembek aspal eksisting

\begin{tabular}{ccc}
\hline \hline Macam Pengujian & Hasil Pengamatan & Keterangan \\
\hline Benda Uji 1 & $52.1^{\circ} \mathrm{C}$ & Aspal \\
Benda Uji 2 & $52.2^{\circ} \mathrm{C}$ & Jatuh pada \\
Plat ke 2 \\
Hasil rata-rata & $52.1^{\circ} \mathrm{C}$ & \\
\hline
\end{tabular}

Dari hasil uji titik lembek, didapat nilai titik lembek untuk aspal eksisting sebesar $52.1^{\circ} \mathrm{C}$.

\section{4) Pemeriksaan Nilai Titik Nyala/Bakar Aspal Eksisting}

Pemeriksaan aspal yang mengacu pada SNI-06-2433-2011 dan ASTM D-92 ini bertujuan untuk menentukan titik nyala dan titik bakar dari semua jenis hasil minyak bumi kecuali bahan minyak bakar dan bahan lainnya yang mempunyai titik nyala open cup kurang dari $79^{\circ} \mathrm{C}[3][4]$. Hasil uji menunjukkan sebagai berikut

Tabel 3

Hasil uji titik nyala/bakar aspal eksisting

\begin{tabular}{ccc}
\hline \hline Macam Pengujian & Hasil Pengamatan & Keterangan \\
\hline Benda Uji 1 & $332^{\circ} \mathrm{C}$ & Terjadi Titik \\
Benda Uji 2 & $333^{\circ} \mathrm{C}$ & Nyala \\
Hasil rata-rata & $333.5^{\circ} \mathrm{C}$ & \\
\hline \hline
\end{tabular}

5) Pemeriksaan Nilai Daktilitas Aspal Eksisting

Pemeriksaan daktilitas aspal yang mengacu pada peraturan AASHTO T-51-74 bertujuan untuk mengetahui sifat kohesi dalam aspal itu sendiri yatiu dengan mengukur jarak terpanjang yang dapat ditarik antara 2 cetakan yang berisi bitumen keras sebelum putus, pada suhu dan kecepatan tarik 
tertentu. Sifat reologi daktilitas digunakan untuk mengetahui ketahanan aspal terhadap retak dalam penggunaannya sebagai lapis perkerasan[3][4].

Tabel 4

Hasil uji titik daktilitas aspal eksisting

\begin{tabular}{ccc}
\hline \hline Macam Pengujian & Hasil Pengamatan & Keterangan \\
\hline Benda Uji 1 & $>100 \mathrm{~cm}$ & Aspal Tidak Putus \\
Benda Uji 1 & $>100 \mathrm{~cm}$ & \\
Hasil rata-rata & $>100 \mathrm{~cm}$ & \\
\hline \hline
\end{tabular}

B. Pengaruh Karakteristik Aspal Runway dengan Kondisi Penerbangan

Pada sub bab ini, penulis akan menyajikan hasil uji Marshall campuran aspal yang digunakan sebagai campuran pada overlay runway Bandara Juanda kemudian melakukan analisis terhadap pengaruh kondisi penerbangan saat ini. Kondisi runway saat ini sesuai dengan informasi yang diberikan oleh PT. Angkasa Pura II dalam hal ini, pengelola Bandara Juanda, menunjukkan bahwa terdapat beberapa jenis kerusakan yang terjadi pada runway. Jenis-jenis kerusakan pada konstruksi perkerasan di bandara tertuang pada peraturan yaitu KP 94 Tahun 2015 Pedoman Teknis Operasional Peraturan Keselamatan Penerbangan Sipil. Maka, overlay ini dilakukan karena adanya kerusakan di runway dan umur runway yang sudah mencapai batas waktu perawatan. Kerusakan yang terjadi pada runway Juanda adalah jenis kerusakan lubang (potholes) dan erosi akibat jetblast (jetblasterotion).

\section{1) Jenis kerusakan lubang atau potholes}

Kerusakan lubang atau potholes merupakan lanjutan dari kerusakan sebelumnya yaitu retak yang tidak segera ditangani cara perbaikan kerusakan ini dengan cara melakukan pemotongan local (patching) secara tegak lurus yang melipputi seluruh area yang terdapat lubang hingga membentuk segi empat, kemudian diisi dengan campuran aspal panas/hotmixasphalt (AC/ATB) sesuai spesifikasi teknis dan metode pelaksanaan [5][6]. Beban lalu lintas adala beban berulang yang menyebabkan kelelahan pada lapisan dari struktur perkerasan [7]. Maka, salah satu kriteria desain untuk aspal beton adalah kelelahan retak. Keretakan/cracking inilah yang menjadi salah satu penyebab kerusakan jenis potholes [8]. Dalam jurnal S.M.J.G. Erkens and J.Moraal. Cracking in Asphalt Concrete. Delft University of Technology menuliskan bahwa terjadi deformasi pada lapisan perkerasan aspal dengan beban kontinu dengan beban $1000 \mathrm{MPa}$ sebesar $0.425 / \mathrm{mm}$ pada temperature $20^{\circ} \mathrm{c}$ [8].

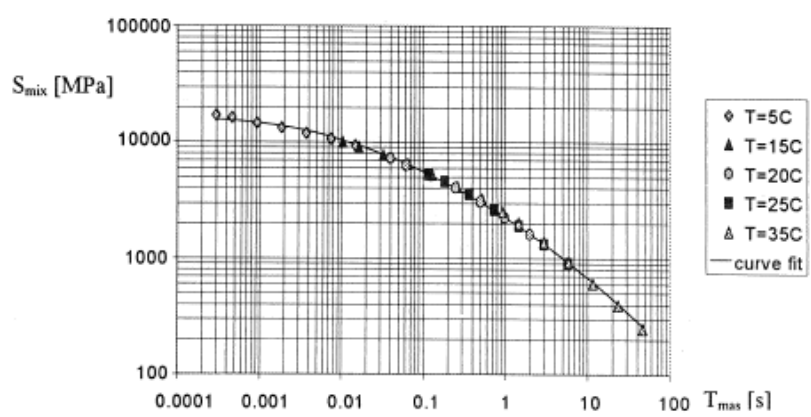

Grafik 1. Hubungan antara kekakuan dengan temperature [8]

\section{2) Jenis kerusakan Jetblast Erotion}

Jet balst adalah istilah dalam pengendalian lalu lintas udara yang mengacu pada gas kecepatan tinggi dan panas yang dipancarkan oleh mesin jet terutama saat lepas landas [9]. Voritisitas adalah sirkulasi fluida. Aspek utama dari bahaya jet blast adalah besarnya ledakan dan area yang terkena dampak [9]. Literature yang membahas tentang pengukuran fenomena jetblast masih kecil. Secara khusus, hanya sedikit studi eksperimental yang telah selesai membahasa mengenai jetblast dengan sekala penuh pada tahun 1970an.

Besarnya suhu mesin jet tempur sebesar $1200^{\circ} \mathrm{C}$. Ketika modern jet engine beroperasi pada dorongan level tinggi (saat take off), ledakan mesinnya bisa mencapau 325 knot setelah mesin aktif. Sedangkan untuk jenis pesawat komersial Boeing atau Airbus besarnya temperatur jet engine ketika kondisi take off sebesar $137^{\circ} \mathrm{C}$ pada titik nozzle dan $38^{\circ} \mathrm{C}$ pada daerah ujung radiasi panas dari jet engine [10][11].

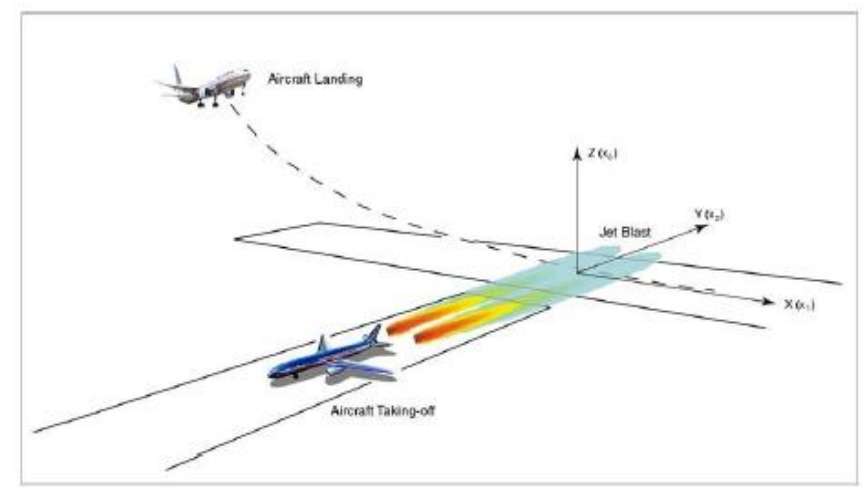

Gambar 1. Ilustrasi jetblast pada cross section runway [9]

\section{Pengaruh Karakteristik Material dan Uji Marshall} dengan Data Kondisi Penerbangan saat ini

\section{1) Stabilitas vs Kerusakan lubang (potholes)}

Hubungan stabilitas dengan kerusakan lubang yang terjadi di runway bandara berkaitan dengan kekuatan campuran aspal beton menerima beban. Stabilitas adalah besarnya beban maksimum yang dapat dicapai oleh bahan susun campuran beraspal panas yang dinyatakan dalam satuan beban. Stabilitas merupakan indikator kekuatan lapis perkerasan dalam memikul beban lalu lintas. Stabilitas campuran dalam pengujian Marshall ditunjukkan dengan pembacaan nilai stabilitas yang dikoreksi dengan angka tebal benda uji

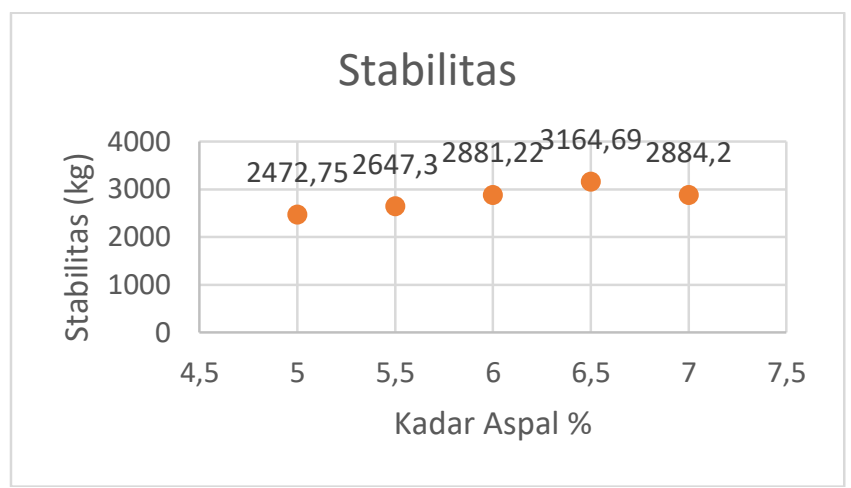

Grafik 2. Hubungan kadar aspal dengan stabilitas

Pada grafik 4.4 ini menunjukkan bahwa pengaruh kadar /aspal terhadap perubahan nilai stabilitas tidak terlalu besar sehingga apabila dalam proses mix design terjadi human error, selama masih dalam batas rentang kadar aspal yang ditentukan sebagai kadar optimum tidak menjadi permasalahan. Kerusakan lubang atau potholes pada kasus ini bisa disebabkan faktor lain tapi masih berkaitan dengan 
nilai stabilitas campuran seperti intensitas penerbangan yang meningkat dari tahun sebelumnya mengakibatkan pembebanan yang terjadi melebihi kemampuan rencana runway dalam menahan beban atau disebabkan umur dari aspal beton yang sudah melebihi batas rencana.

\section{2) Titik Lembek vs Jetblast Erotion}

Temperatur pada saat dimana aspal mulai menjadi lunak tidaklah sama pada setiap hasil produksi aspal walaupun mempunyai nilai penetrasi yang sama. Aspal dengan titik lembek yang lebih tinggi kurang peka terhadap perubahan temperatur dan lebih baik untuk bahan pengikat konstruksi [3].

Tabel 5

Hasil uji titik lembek aspal eksisting

\begin{tabular}{ccc}
\hline \hline Macam Pengujian & Hasil Pengamatan & Keterangan \\
\hline Benda Uji 1 & $52.1^{\circ} \mathrm{C}$ & Aspal Jatuh pada \\
Benda Uji 2 & $52.2^{\circ} \mathrm{C}$ & Plat ke 2 \\
Hasil rata-rata & $52.1^{\circ} \mathrm{C}$ &
\end{tabular}

Dari hasil uji titik lembek, didapat nilai titik lembek untuk aspal eksisting sebesar $52.1^{\circ} \mathrm{C}$. Pengaruh titik lembek terkait kerusakan akibat jet engine pesawat berkaitan dengan perubahan sifat aspal ketika menerima panas. Titik lembek ini menunjukkan bahwa perubahan sifat thermoplastic aspal Shell eksisting terjadi pada suhu $52.1^{\circ} \mathrm{C}$. Pada suhu ini menunjukkan perubahan sifat aspal menjadi lebih lunak sehingga dapat menyebabkan terlepasnya material dari campuran aspal pada suhu tersebut.

Di Bandara Juanda beroperasi dua jenis pesawat, yaitu pesawat militer dan pesawat komerisal. Besarnya suhu mesin jet tempur sebesar $1200^{\circ} \mathrm{C}$. Ketika modern jet engine beroperasi pada dorongan level tinggi (saat take off), ledakan mesinnya bisa mencapau 325 knot setelah mesin aktif. Sedangkan untuk jenis pesawat komersial Boeing atau Airbus besarnya temperatur jet engine ketika kondisi take off sebesar $137^{\circ} \mathrm{C}$ pada titik nozzle dan $38^{\circ} \mathrm{C}$ pada daerah ujung radiasi panas dari jet engine.

Dari kondisi ini, dapat disimpulkan bahwa pengaruh panas jet engine yang dihasilkan pesawat komerisal tidak terlalu berpengaruh terhadap karakteristik aspal tetapi khusus pada titik tertentu yang dekat dengan titik nozzle jet engine, hal ini yang menyebabkan terjadinya jetblast erotion sebab panas yang dihasilkan pada titik ini mencapai $137{ }^{\circ} \mathrm{C}$ sehingga dapat menyebabkan perubahan sifat aspal menjadi lunak dan terlepas dari campuran aspal beton.

\section{Pembahasan Hasil Uji Marshall}

\section{1) Pengaruh Kadar Aspal terhadap Nilai Kepadatan campuran $A C-W C$}

Nilai kepadatan menunjukkan besarnya kerapatan suatu campuran yang sudah dipadatkan. Faktor yang mempengaruhi kepadatan adalah temperature pemadatan, gradasi, kadar filler, energi pemadat, kadar aspal, dan porositas butiran [12]. Campuran dengan kepadatan tinggi akan lebih mampu menahan beban yang lebih tinggi. Perbandingan nilai kepadatan antara campuran AC-WC dengan menggunakan aspal pertamina dan aspal Shell dapat dilihat pada tabel dan grafik dibawah

Tabel 4

Perbandingan antara berat benda uji dengan kadar aspal

\begin{tabular}{cccc}
\hline \hline \multirow{2}{*}{ Benda Uji } & \multirow{2}{*}{ Kadar Aspal } & \multicolumn{2}{c}{ Berat isi benda uji } \\
& & Aspal Shell & Aspal Pertamina \\
\hline 1 & 4.16 & 2.34 & 2.32 \\
\hline
\end{tabular}

\begin{tabular}{llll}
\hline 2 & 4.66 & 2.29 & 2.34 \\
3 & 5.16 & 2.33 & 2.34 \\
4 & 5.66 & 2.43 & 2.42 \\
5 & 6.16 & 2.43 & 2.42 \\
\hline \hline
\end{tabular}

2) Pengaruh Kadar Aspal terhadap nilai Void in Mineral Aggregate (VMA) campuran AC-WC

Void in Mineral Agregate (VMA) adalah rongga udara yang berada diantara partikel agregat di dalam suatu campuran beraspal panas yang sudah dipadatkan termasuk ruang yang terisi aspal. VMA digunakan sebagai ruang untuk menampung aspal dan volume rongga udara yang diperlukan dalam campuran beraspal panas. Besarnya nilai VMA dipengaruhi oleh kadar aspal, gradasi bahan susun, jumlah tumbukan dan temperatur pemadatan. VMA dihitung berdasarkan brat jenis bulk agregat dan dinyatakan sebagai persen volume bulk campuran yang dipadatkan. VMA dapat dihitung pila terhadap berat campuran total atau terhadap berat agregat total [12]. Hasil pengujian untuk masingmasing jenis material aspal disajikan di bawah ini

Tabel 5

Hubungan antara persen rongga agregat dengan kadar aspal

\begin{tabular}{cccc}
\hline \hline Benda Uji & Kadar Aspal & \multicolumn{2}{c}{ Persen rongga terhadap agregat } \\
& & Aspal Shell & Aspal Pertamina \\
\hline 1 & 4.16 & 16.87 & 17.53 \\
2 & 4.66 & 18.90 & 17.31 \\
3 & 5.16 & 18.09 & 17.83 \\
4 & 5.66 & 15.00 & 15.29 \\
5 & 6.16 & 15.28 & 15.85 \\
\hline \hline
\end{tabular}

3) Pengaruh Kadar Aspal terhadap nilai Void Filled Asphalt (VFA) campuran AC-WC

VFA (Void Filled Asphalt), menyatakan presentase rongga udara yang terisi aspal pada campuran aspal yang telah mengalami pemadatan. Nilai VFA ini merupakan sifat kekedapan air dan udara, maupun sifat elastis campuran. Nilai VFA dipengaruhi oleh beberapa factor seperti : energi, suhu pemadatan, jenis, dan kadar aspal, serta gradasi agregatnya. Besarnya nilai $V F A$ menentukan keawetan suatu campuran beraspal panas, semakin besar nilai $V F B$ akan menunjukkan semakin kecil nilai $V F A$ yang berarti rongga terisi aspal semakin banyak, oleh karena itu campuran beraspal panas akan semakin awet. Begitu sebaliknya, apabila VFA terlalu kecil, maka rongga yang terisi aspal akan semakin sedikit sehingga agregat yang terselimuti aspal akan tipis yang menyebabkan campuran beraspal panas tidak awet [12]. Hasil pengujian dan hubungan antara kadar aspal dengan Void Filled Asphalt disajikan sebagai berikut Tabel 6

Hubungan antara kadar aspal dengan persen rongga pada aspal

\begin{tabular}{cccc}
\hline \hline Benda Uji & Kadar Aspal & \multicolumn{2}{c}{ Persen rongga terhadap aspal } \\
& & Aspal Shell & Aspal Pertamina \\
\hline 1 & 4.16 & 55.79 & 53.54 \\
2 & 4.66 & 54.73 & 61.23 \\
3 & 5.16 & 64.27 & 65.74 \\
4 & 5.66 & 88.71 & 87.11 \\
5 & 6.16 & 94.93 & 91.36 \\
\hline \hline
\end{tabular}




\section{4) Pengaruh Kadar Aspal terhadap Nilai Void In Mix (VIM)} campuran $A C$-WC

VIM (Void In Mix) adalah banyaknya rongga dalam campuran yang dinyatakan dalam persentase. Rongga udara yang terdapat dalam campuran diperlukan untuk tersedianya ruang gerak untuk unsur-unsur campuran sesuai dengan sifat elastisitasnya. Karena itu nilai VIM sangat menentukan karakteristik campuran. Nilai VIM dipengaruhi oleh gradasi agregat, kadar aspal, dan density dengan bertambahnya kadar aspal, maka jumlah aspal yang mengisi rongga antar butiran agrega semakin bertambah sehingga volume rongga dalam campuran semakin berkurang [12]. Hasil pengujian disajikan sabagai berikut

Tabel 7

Hubungan antara kadar aspal dengan persen rongga pada campuran Benda Uji $\quad$ Kadar Aspal Persen rongga terhadap campuran

\begin{tabular}{cccc} 
& & Aspal Shell & Aspal Pertamina \\
\hline 1 & 4.16 & 7.46 & 8.14 \\
2 & 4.66 & 8.56 & 6.71 \\
3 & 5.16 & 6.46 & 6.11 \\
4 & 5.66 & 1.69 & 1.97 \\
5 & 6.16 & 0.78 & 1.37 \\
\hline \hline
\end{tabular}

5) Pengaruh Kadar Aspal terhadap Nilai Stabilitas campuran $A C-W C$

Stabilitas adalah besarnya beban maksimum yang dapat dicapai oleh bahan susun campuran beraspal panas yang dinyatakan dalam satuan beban. Stabilitas merupakan indicator kekuatan lapis perkerasan dalam memikul beban lalu lintas. Stabilitas campuran dalam pengujian Marshall ditunjukkan dengan pembacaan nilai stabilitas yang dikoreksi dengan angka tebal benda uji [12]. Hasil pengujian stabilitas Marshall disajikan pada tabel dan grafik di bawah ini

Tabel 8

Hubungan antara kadar aspal dengan nilai stabilitas

\begin{tabular}{cccc}
\hline \hline Benda Uji & Kadar Aspal & \multicolumn{2}{c}{ Stabilitas } \\
& & Aspal Shell & Aspal Pertamina \\
\hline 1 & 4.16 & 2268.63 & 2234.26 \\
2 & 4.66 & 1581.17 & 2268.63 \\
3 & 5.16 & 1993.65 & 1924.90 \\
4 & 5.66 & 1168.69 & 1684.29 \\
5 & 6.16 & 1478.05 & 1443.68 \\
\hline \hline
\end{tabular}

\section{KESIMPULAN DAN SARAN}

\section{A. Kesimpulan}

Setelah dilakukan pengujian terhadap dua material aspal yang digunakan sebagai material pengikat pada campuran aspal beton runway Bandara Juanda, yaitu aspal Pertamina dan aspal Shell. Didapat hasil uji yang kemudian dianalisis dan digunakan sebagai jawaban atas rumusan masalah pada studi ini. Kesimpulannya adalah sebagai berikut :

\section{1) Karakteristik material runway Bandara Juanda}

Karakteristik material ditunjukkan dengan hasil uji laboratorium, didapatkan untuk uji material aspal, nilai penetrasi aspal Shell eksisting sebesar $63.67 \mathrm{~mm}$, nilai titik lembek sebesar $52.1^{\circ} \mathrm{C}$, nilai titik nyala dan titik bakar terjadi pada suhu $333.5^{\circ} \mathrm{C}$, nilai daktilitas mencapai $>100 \mathrm{~cm}$, dan nilai berat jenis sebesar $1.0332 \mathrm{gr} / \mathrm{m}^{3}$. Kemudian didapatkan untuk uji material agregat, nilai keausan yang didapat adalah sebesar $23.04 \%$ dari persyarataan $25 \%$, nilai berat jenis sebesar 2.749, dan nilai abrasi sebesar 1.556.

\section{2) Pengaruh karakteristik material terhadap kondisi eksisting runway Bandara Juanda}

Setelah dilakukan uji karakteristik kemudian dilakukan uji mix design dengan menggunakan Uji Marshall, didapatkan nilai kepadatan sebesar $2.437 \mathrm{gr} / \mathrm{cc}$, nilai VIM sebesar $3.57 \%$ pada kadar $6 \%$ dengan persyaratan VIM antara 3-4\%, nilai VFA sebesar $77.32 \%$ pada kadar $6 \%$ dengan persyaratan antara $76-82 \%$, nilai stabilitas sebesar $2881.22 \mathrm{lbs}$ pada kadar $6 \%$ dengan persyaratan diatas $1800 \mathrm{lbs}$, nilai flow sebesar $3.89 \mathrm{~mm}$ pada kadar $6 \%$ dengan persyaratan diantara 2-4 mm, dan MQ sebesar 7.4. Dari hasil ini kemudian dilakukan analisis hubungan dengan kerusakan yang terjadi di runway Bandara Juanda, kerusakan yang terjadi berupa lubang dan pengikisan atau jetblast erotion.

Diambil kesimpulan bahwa pengaruh kadar aspal terhadap perubahan nilai stabilitas tidak terlalu besar sehingga apabila dalam proses mix design terjadi human error, selama masih dalam batas rentang kadar aspal yang ditentukan sebagai kadar optimum tidak menjadi permasalahan. Kerusakan lubang atau potholes pada kasus ini bisa disebabkan faktor lain tapi masih berkaitan dengan nilai stabilitas campuran seperti intensitas penerbangan yang meningkat dari tahun sebelumnya mengakibatkan pembebanan yang terjadi melebihi kemampuan rencana runway atau disebabkan umur dari aspal beton yang sudah melebihi batas rencana. Kemudian untuk kerusakan akibat jetblast pengaruh panas jet engine yang dihasilkan pesawat komerisal tidak terlalu berpengaruh terhadap karakteristik aspal tetapi khusus pada titik tertentu yang dekat dengan titik nozzle jet engine, hal ini yang menyebabkan terjadinya jetblast erotion sebab panas yang dihasilkan pada titik ini mencapai $137{ }^{\circ} \mathrm{C}$ sehingga dapat menyebabkan perubahan sifat aspal menjadi lunak dan terlepas dari campuran aspal beton.

\section{3) Perbandingan antara aspal Shell dengan aspal Pertamina}

Didapat dari hasil uji karakteristik dan uji Marshall bahwa kualitas aspal Shell lebih baik dibandingkan dengan aspal Pertamina, hal ini terlihat dari beberapa hasil pengujian, seperti nilai penetrasi aspal Shell sebesar $63.2 \mathrm{~mm}$ dan aspal Pertamina $63.9 \mathrm{~mm}$ berarti aspal Shell memiliki sifat lebih kaku dibandingkan aspal Pertamina hal ini mempengaruhi nilai stabilitas aspal beton ketika menerima beban. Nilai titik lembek aspal Shell sebesar $53.5^{\circ} \mathrm{C}$ sedangkan nilai titik lembek aspal Pertamina sebesar $52.5^{\circ} \mathrm{C}$ hal ini menunjukkan bahwa aspal Pertamina lebih mudah mengalami perubahan sifat saat menerima panas. Nilai daktilitas aspal Shell sebesar $142 \mathrm{~mm}$ sedangkan aspasl Pertamina sebesar $139 \mathrm{~mm}$. Nilai berat jenis aspal Shell sebesar $1.033^{\mathrm{gr}} / \mathrm{m}^{3}$ sedangkan aspal Pertamina sebesar $1.028^{\mathrm{gr}} / \mathrm{m}^{3}$. Nilai titik nyala dan titik bakar aspal Shell mencapai $302{ }^{\circ} \mathrm{C}$ dan $324^{\circ} \mathrm{C}$, sedangkan untuk aspal Pertamina adalah $280{ }^{\circ} \mathrm{C}$ dan $310{ }^{\circ} \mathrm{C}$. Hal tersebut memungkinkan aspal Pertamina memiliki kepekaan terhadap suhu yang lebih besar disbanding aspal Shell. Maka, secara keseluruhan aspal Shell memiliki karakteristik yang lebih baik dibandingkan aspal Pertamina untuk memenuhi spesifikasi dan kondisi runway Bandara Juanda 


\section{B. Saran}

Pada studi ini terdapat beberapa saran untuk melengkapi agar studi ini memiliki dasaran yang lebih kuat, diantaranya sebagai berikut :

a. Pada studi selanjutnya disajikan uji ekstraksi dari benda uji yang telah dibuat. Diharapkan dengan adanya uji ekstraksi dapat mengupas lebih detail karakter masing-masing material aspal.

b. Dilakukan pembahasan terkait biaya yang diperlukan sehingga diperlukan perbandingan biaya yang dibutuhkan apabila memilihi material yang akan digunakan sebagai campuran aspal beton.

c. Adanya pembahasan tentang modifikasi yang harus dilakukan agar aspal Pertamina bisa menyeimbangi karakteristik aspal Shell.

\section{DAFTAR PUSTAKA}

[1] F. Leily, "Kinerja Aspal Pertamina Pen 60/70 Dan Aspal Bna Blend 75/25 Pada Campuran Aspal Panas Ac-Wc," Tek. Sipil Polines, 2013.

[2] T. Hary, "Evaluasi Kekuatan Perkerasan Sisi Udara
(Runway,Taxiway,Apron) Bandara Juanda Dengan Metode Perbandingan ACN-PCN," Tek. Sipil ITS, 2015.

[3] S. Silvia, Perkerasan Lentur Jalan Raya. Bandung: Nova Publisher, 1999.

[4] Gavirariesa Tiara, "Pengaruh Temperatur terhadap Penetrasi Aspal Pertamina dan Aspal Shell," Jur. Tek. Sipil Itenas, 2015.

[5] K. H. K, "Low-Temperature Cracking: Field Validation of the Thermal Stress Restrained Specimen Test," Civ. Eng. Oregon State Univ., 1994.

[6] S. Abu, "Crack Survey, Crack Repair Methodology and Overlay Design for Rehabilittion of a Runway Pavement," Civ. Eng. Bangladesh Univ. Eng., 2005.

[7] D. C. Bertrand, Applying Take Off Thrust on Unsuitable pavement Surface may hae Hidden Dangers. France: Aircraft Operation, 2004

[8] E. S. M. J. . and J. Moral, "Cracking in Asphalt Concrete," Civ. Eng. Delft Univ. Technol., 1996.

[9] S. P. E, An Operational Model for the Prediction of Jet Blast. Cambridge: Transportation Systems Center.

[10] Airbus, Airplane Characteristics for Airport Planning. France, 2012.

[11] Boeing, Airplane Characteristic for Airplan Planning. America, 2013.

[12] M. Faqih., "Efek variasi Kadar Bitumen terhadap Kinerja Marshall Laboratorium dengan Menggunakan Agregat Bantak," Tek. Sipil UNY, 2012 